\title{
Research on Countermeasures to Improve the Effect of Case Teaching in Western Economics Course
}

\author{
Zejiong Zhou" ${ }^{1, *}$, Li Han ${ }^{1}$ \\ ${ }^{1}$ School of Economics, Anhui University of Finance and Economics, Bengbu, Anhui, China \\ *aczzj123456@163.com
}

\begin{abstract}
A perfect case teaching process is the premise to ensure the case effect of western economics course. At present, there are many deficiencies in the case teaching process of western economics course in China. This paper first analyzes the shortcomings in the case teaching process of western economics course, puts forward perfect ideas, and then points out how to correctly deal with the relationship between case teaching and theoretical teaching, the relationship between teachers' leadership and students' subject, the relationship between case teaching methods and students' quality.
\end{abstract}

Keywords: Western economics course, Case teaching, Teaching method.

\section{Introduction}

Western economics is one of the most important professional basic courses for economic management majors in Colleges and universities in China. Through the study of this course, students can master the basic theoretical knowledge of economics and have the ability to analyze and solve practical economic problems, so as to lay a good foundation for further study of professional courses. However, western economics is a general abstraction and generalization of the development law of market economy in western countries for hundreds of years. Its theoretical formation background is different from that in China. In addition, many theories are explained by a large number of formulas and geometric figures. Students feel abstracted and difficult to understand when learning western economics courses. Therefore, it is necessary to flexibly use the case teaching method to present the western economic theory to students in a vivid form. Many domestic colleges and universities have made various explorations and attempts on the case teaching of western economics, and gained useful experience. However, the case teaching of western economics in China is still in the exploratory stage, and there are still many deficiencies in the implementation process, which need to be improved.

Domestic scholars have conducted extensive research on the case teaching of western economics. Yang Xiao, Zhao Xiaokui (2016) believes that case teaching is the first choice of economics teaching means, but most of the teaching cases of western economics come from the practice of market economy in western developed countries. The lack of localized case resources leads to the decline of students' interest in learning and can not accurately understand and grasp the principles of Economics [1]. Cao Xin (2017) believes that the application of participatory teaching method is mainly to guide college students to participate in western economics classroom teaching by guiding college students' innovation and entrepreneurship projects. The application of case teaching method is mainly to stimulate students' interest in discussion by summarizing practical problems in economic life into cases [2]. Mong Dan (2017) believes that according to the teaching content, students' knowledge and ability foundation, the phased case teaching mode in western classics teaching can effectively play a role in case teaching through a series of scientific implementation means, such as the selection of appropriate stage case teaching objectives, the correct positioning of the roles of teachers and students in stage case teaching, appropriate case selection and good classroom organization Unique advantages in ability training [3]. Zhou Zhenpeng (2018) believes that western economics is highly abstract and requires high mathematical knowledge, but it is also a highly applied course. Case teaching helps to improve students' interest in learning and cultivate students' ability to solve practical economic problems. At present, there are some problems in teaching, such as lax cases, lack of comprehensive cases, few hot cases and few quantitative analysis cases. It is suggested that the selected cases should be comprehensive, and the cases should be combined with students' life, majors, real economic hot spots and quantitative analysis [4]. Wang Hui (2019) believes that the case teaching method is widely used in teaching at home and abroad. Western countries usually use this method for teaching, and so does China. In western economics, case teaching method is usually its auxiliary learning, and it can also lay the foundation for learning economics well [5]. Xu Qigao (2020) believes that although case teaching has more and more applications in the teaching of western economics, it uses more foreign cases, less local cases and less local cases. This is undoubtedly a defect for the realization of the training goal of applied economic management talents majoring in economic management in local colleges and universities [6]. Liu Weiming et al (2021) believes that western economics is a basic course for all majors of economics, and its teaching effect has a far-reaching impact on students' learning, understanding and analysis of other courses. The introduction of "case modularization" in classroom teaching can stimulate students' learning enthusiasm and improve the teaching effect. The "case modularization" teaching requires teachers to change their teaching ideas and improve the teaching effect "case modularization" design and timely summarize the "case modularization" Teaching [7]. 


\section{Deficiencies and Improvement Ideas in the Case Teaching Process of Western Economics}

The process of case teaching generally includes the design of teaching cases, the application of case teaching methods and the evaluation of case teaching effects. At present, there are some deficiencies in several links of case teaching of western economics in China, which affects the effect of case teaching to a great extent. The following will analyze the problems existing in the case teaching process of western economics and put forward improvement ideas.

\subsection{Design of Teaching Cases}

Designing reasonable teaching cases is the premise and basis for the successful implementation of case teaching. At present, the case teaching of western economics in China mostly selects foreign original textbook cases, and the lack of localized cases seriously affects the effect of case teaching. The foreign original textbooks are rich in cases, diverse in forms, popular and intuitive, and have been widely recognized by domestic scholars. However, these cases come from the market economic system of western developed capitalist countries, which is far from China's socio-economic environment, and can not better reveal the characteristics of China's economic operation. When learning relevant cases, students are difficult to grasp the economic principles reflected in the cases because they do not understand the economic and social background of foreign cases, and can not correctly analyze the actual economic problems faced by our country by using economic theory after learning relevant cases. Therefore, in view of the problems existing in the existing cases of western economics, compiling some cases in line with domestic economics teaching is an urgent problem to be solved. There are two main ways to compile economic cases: first, teachers obtain "first-hand" materials through social practice and investigation and research by virtue of their keen observation and generalization of economic phenomena. After obtaining "first-hand" materials, give full play to teachers' deep understanding and grasp of economic theory, and write some authentic and typical cases. Through the investigation of agricultural product output and farmers' income in different years in some areas, the case of "grain cheap hurts farmers" is compiled. Through the investigation of residents' income level and consumption expenditure in some areas, the cases of average consumption propensity and marginal consumption propensity are compiled. The second is to obtain "second-hand" information through the analysis and reporting of relevant economic problems in newspapers, magazines, television and the Internet. After obtaining the "second-hand" materials, the teacher compiles economic cases with his strong abstract generalization ability and material selection ability. For example, use the tobacco and alcohol tax adjustment policy and the changes of tobacco and alcohol prices reported by TV news to compile the cases of commodity price elasticity and tax transfer. Due to the limitation of teachers' ability and time, it is unrealistic for all economic cases to be compiled by teachers themselves. It is necessary to select some teaching cases from the existing western economics textbooks. In the process of selecting cases, the following principles should be followed: first, the principle of typicality. Typical cases can often directly and clearly explain some complex economic principles. It is also a case recognized by economics teaching at home and abroad.
In the teaching of Coase theorem, the case of "cattle eat grain in the adjacent valley" is discussed, and in the teaching of externality principle, the case of "bees and orchards" is discussed. Discuss the "used car market" in the teaching of incomplete information theory. Discuss "prisoner's dilemma" in the teaching of dominant strategic equilibrium theory. The second is the principle of timeliness and reality. Some cases in western economics textbooks illustrate the economic problems many years ago. These cases can not arouse students' interest in learning, nor are they conducive to the cultivation of students' ability to analyze practical problems. The selected economic cases should have timeliness and reality. For example, at this stage, the case of "cost of graduate students" is discussed in the teaching of opportunity cost theory, and the "effect of active fiscal policy and moderately loose monetary policy" is discussed in the teaching of macroeconomic policy effect theory.

\subsection{Application of Case Teaching Method}

After selecting and compiling cases, teachers flexibly use a variety of case teaching methods according to the classroom teaching content, so as to improve the effect of case teaching. Affected by the teaching mode and class hour restrictions, at present, the case teaching method of western economics course in some schools in China is single. Only some cases are given in the process of theoretical teaching, and the effect of case teaching is very unsatisfactory. Not only the case itself can not arouse students' interest, but also the case analysis can not help students' understanding of economic theory. According to the case teaching experience of western economics courses for many years, and based on the case teaching experience of economics and other economic management courses at home and abroad, this paper puts forward the following case teaching methods of western economics courses.

\subsubsection{Interleaved Case Teaching Method}

In the process of systematically explaining the principles of economics, some cases are interspersed to enable students to understand the basic principles through cases. There should not be too many interspersed cases, mainly for the key points and difficulties of teaching, otherwise it will affect the progress of classroom teaching. The interspersed cases should not be too complex, and should be as concise and clear as possible, so as to avoid students' ambiguity on the economic theory problems to be explained. For example, when explaining the theory of consumer behavior, we analyze the law of diminishing marginal utility through the case of "eating bread". When explaining the equilibrium price theory, this paper analyzes the impact of support price on commodity equilibrium price and equilibrium output through the case of "grain protection price". When explaining the theory of price discrimination, this paper analyzes the three-level price discrimination through the case of "the difference of advertising expenses between prime time and non prime time". The interspersed case teaching method requires teachers to be very familiar with case materials and be able to come at their fingertips in the process of theoretical explanation.

\subsubsection{Discussion Case Teaching Method}

According to whether the economic principles used in case analysis span chapters or not, the discussion case teaching method is divided into small case discussion and comprehensive case discussion. (1) Small case discussion. After teaching one or a chapter of economic theory, the 
teacher puts forward small case materials and analysis problems for students to analyze and discuss, and the teacher finally summarizes. For example, after talking about "manufacturer theory", guide students to discuss the case of "price war in notebook computer market"; after talking about "imperfect competition market theory", guide students to discuss "Telephone charges of telecom companies", "electricity prices of power companies" and other cases; After talking about the "simple national income determination theory", guide students to discuss cases such as "the impact of government increased infrastructure investment on economic growth". At this time, the students have not systematically mastered the principles of economics and have poor comprehensive analysis ability. The cases provided should closely follow the taught theories, and should not be too complex. (2) Comprehensive case discussion. After teaching a few chapters of economic theory, teachers consciously provide some comprehensive cases involving cross chapters for students to analyze and discuss, so as to cultivate students' ability to analyze and deal with practical economic problems with complex contents and many clues. For example, after talking about production theory, cost theory and manufacturer theory, organize students to discuss. The case of problems exists in the operation and management of family enterprises and their countermeasures. After talking about the theory of national income determination, fiscal policy and monetary policy, organize students to discuss the case of "what impact China's active fiscal policy has on economic development". The selected cases for comprehensive case discussion should be highly comprehensive and difficult. At the same time, case materials and questions should be provided to students in advance so that students can make necessary preparations. These cases themselves are controversial, and their conclusions are diverse and open. Therefore, teachers should encourage students to express their views and put forward their views from all angles and levels.

\subsubsection{Thematic Debate Case Teaching Method}

For some comprehensive major cases involving multiple knowledge points, students can be divided into positive and negative groups, and case teaching can be carried out in the way of thematic debate. For example, after teaching the theory of welfare economics, I asked, "does the decline in the proportion of wage income of China's labor force lead to the decline of the whole social welfare level?". After teaching the theory of macroeconomic policy, I asked, "should China adopt an expanding monetary policy or a tightening monetary policy at this stage?". Through the symposium, students' interest in learning economic theory can be fully mobilized, students can actively find information and think about problems, and students' ability to analyze real economic problems with economic theory can be improved. During the implementation of the symposium, in addition to preparing case materials and designing debate issues, teachers should also maintain the debate order, stimulate positive and negative students to think actively and fully express their views. Because this case teaching method consumes a lot of time for teachers and students. It should not be used frequently. It should be held once in the learning process of microeconomics and macroeconomics.

\subsection{Evaluation of Case Teaching Effect}

The evaluation of case teaching effect is an important link in the process of case teaching and a powerful guarantee to improve the effect of case teaching. At present, the case teaching of western economics in some schools lacks effective measures to evaluate the effect of case teaching. In order to improve the effect of case teaching in western economics, we should make an objective evaluation on case design, case teaching means, students' team spirit and students' understanding of cases after the completion of case teaching. Firstly, the case design is evaluated. If the content of the case is appropriate, difficult and appropriate, which is conducive to the understanding and mastery of economic theoretical knowledge, a positive evaluation will be given. Otherwise, the content of the case should be adjusted. Secondly, it evaluates the case teaching methods. If modern teaching methods, especially multimedia teaching, are reasonably used in the process of case teaching, a positive evaluation will be given. Case teaching methods should be improved. Thirdly, evaluate the students' team spirit. If in the case discussion, the students in the group have a clear division of labor and can absorb correct views from each other, they will be given a positive evaluation. Otherwise, we should improve students' team spirit. Finally, the effect of case teaching is evaluated. If after the case teaching, the students fully understand the relevant economic principles and improve their practical analysis ability, they will be given a positive evaluation. Otherwise, we should improve the case teaching method and improve the case teaching process. The after-school evaluation subjects of case teaching include students, teachers themselves and teachers and experts of western economics invited in case teaching. Before case teaching evaluation, the evaluation contents and methods of these evaluation subjects should be clarified. After the evaluation results of different evaluation subjects come out, they should also be comprehensively sorted out to obtain objective evaluation results and put forward effective improvement measures.

\section{Several Relations that should be Handled in the Case Teaching of Western Economics}

In order to ensure the effective implementation of case teaching in western economics, in addition to perfecting the above main links, we should also correctly deal with several relationships, namely, the relationship between case teaching and theoretical teaching, the relationship between teachers' leadership and students' subject, the relationship between case teaching methods and students' quality.

\subsection{Correctly Handle the Relationship Between Case Teaching and Theory Teaching.}

From the perspective of the curriculum system of economic management specialty, western economics is a professional basic course. Its teaching purpose is to enable students to systematically master the basic principles of economics and be able to use these basic principles to analyze and solve practical economic problems. Therefore, the main teaching method of western economics is theoretical teaching, and case teaching is an auxiliary teaching method, which is the extension and deepening of theoretical teaching. Through theoretical teaching, students can systematically master economic theory and have a solid foundation in economic theory. Through case teaching, students can deepen their understanding of theoretical knowledge, stimulate students' 
interest in learning economic theory and improve their ability to analyze and solve practical problems. In the teaching process of western economics, teachers should correctly deal with the subject and auxiliary relationship between case teaching and theory teaching. We can neither emphasize the theoretical teaching method and ignore the case teaching method, nor put the cart before the horse. The case teaching method mainly affects the systematic learning of theoretical knowledge. In addition, the majors offering western economics courses include not only the majors of economic management, but also the majors of science, law and literature. When determining the class hour proportion of case teaching and theory teaching, we should consider the differences of different disciplines.

\subsection{Correctly Handle the Relationship Between Teacher Leadership and Student Subject}

In the traditional teaching of western economics, teachers are often in an absolute dominant position, while students are in a passive position. When teachers teach economic theoretical knowledge and students listen passively, students feel that the teaching content is boring, and their ability to analyze and solve real economic problems can not be exercised. In case teaching, teachers are in the leading position and students are in the main position. In the implementation of case teaching, correctly handling the relationship between teachers' leadership and students' subject is related to the success or failure of case teaching. This requires that we should neither overemphasize the role of teachers and ignore the main role of students, nor overemphasize the main role of students and let them discuss and debate by themselves. In case teaching, the leading role of teachers is mainly reflected in the whole process of case selection, case analysis and discussion and case summary. Before case teaching, teachers need to focus on the teaching content, compile some specific, timely and realistic cases, and design appropriate problems; In the process of case teaching, teachers should organize and guide students to analyze and discuss cases, and give appropriate evaluation to students' views. After case teaching, teachers should evaluate the effect of case teaching in time. In case teaching, students' main role is mainly reflected in the process of case data access, case analysis and discussion. Before comprehensive case discussion and thematic debate, students should actively consult relevant materials as required by teachers; In the process of case discussion and debate, students should actively use their theoretical knowledge to analyze practical problems and boldly express their views under the guidance of teachers. After case teaching, students also need to further consult materials to improve the analysis of cases.

\subsection{Correctly Handle the Relationship Between Case Teaching Methods and Students' Quality}

Interleaved, discussion and thematic debate case teaching methods have different requirements for students' ability to analyze practical problems by using economic theory. Therefore, we should correctly deal with the relationship between case teaching methods and students' quality, so as to make case teaching methods suitable for students' quality. Western economics as a professional basic course, most schools are set up in the freshman or sophomore stage. Students at this stage have just come into contact with economic theory and do not have the ability to use economic theory to analyze real cases. Therefore, case teaching needs to follow the principle of step-by-step. In the initial stage of western economics teaching, teachers should adopt the interleaved case teaching method to analyze some teaching cases in the process of teaching economic theory, so that students can master the case analysis method. After students have mastered the case analysis method, some small case discussions shall be arranged appropriately according to the teaching content. After several small case discussions and the complete teaching of some economic theories, comprehensive case discussions will be arranged. After students systematically master some economic theories and have certain case comprehensive analysis ability, they can hold a case symposium to further train students' ability to analyze and solve practical problems.

\section{References}

[1] Yang Xiao, Zhao Xiaokui. Reflections on the localization of case teaching in western economics [J]. Modern economic information, 2016(09):440-441.

[2] Cao Xin. Exploration on case teaching and participatory teaching of western economics based on innovation and Entrepreneurship Education [J]. Modernization of education, 2017,4(17):134-135.

[3] Mondan. Research on case teaching model of western economics based on ability training [J]. Education and teaching forum, 2017 (43): 178-179.

[4] Zhou Zhenpeng. Application of case teaching method in Western Economics Teaching [J]. Rural economy and science and technology, 2018,29(23):296-298.

[5] Wang Hui. Analysis on the application effect of case teaching method in Western Economics Teaching [J]. Knowledge economy, 2019(10):137-138.

[6] Xu Qigao. Exploration on local case teaching of "western economics" from the perspective of applied talent training goal -- Taking the use of "Jiangling Automobile" series cases in Nanchang as an example [J]. Internal combustion engines and accessories, 2020 (11): 287-288.

[7] Liu Weiming, Hu Zuguang, Shan Shun, Zeng Bing. Exploration on "case modularization" teaching of western economics course $[\mathrm{J}]$. Journal of Hunan First Normal University, 2021, 21(04):84-89. 